Fr. Thomas Joseph White OP*

Thomistic Institute, Angelicum, Rome

\title{
WHY CATHOLIC THEOLOGY NEEDS METAPHYSICS: A CHRISTOLOGICAL PERSPECTIVE
}

The Chalcedonian confession of faith asserts that Christ is one person, the Son of God, subsisting in two natures, divine and human. The doctrine of the communication of idioms is essential to the life and practices of the Church insofar as we affirm there to be properties of deity and humanity present in the one subject, the Word made flesh. Such affirmations are made without a confusion of the two natures or their mutually distinct attributes. The affirmation that there is a divine and human nature in Christ is possible, however, only if it is also possible for human beings to think coherently about the divine nature, analogically, and human nature, univocally. Otherwise it is not feasible to receive understanding of the divine nature of Christ into the human intellect intrinsically and the revelation must remain wholly alien to natural human thought, even under the presumption that such understanding originates in grace. Likewise we can only think coherently of the eternal Son's solidarity with us in human nature if we can conceive of a common human nature present in all human individuals. Consequently, it is only possible for the Church to confess some form of Chalcedonian doctrine if there is also a perennial metaphysical philosophy capable of thinking coherently about the divine and human natures from within the ambit of natural human reason. This also implies that the Church maintains a "metaphysical apostolate" in her public teaching, in her philosophical traditions, as well as in her scriptural and doctrinal enunciations.

The communication of idioms pertains to the language we use in classical Catholic theology to speak about the incarnation of God, just insofar as God the Son, the eternal Word of the Father, has become human, one hypostatic subject

Thomas White OP - is the Director of the Thomistic Institute at the Angelicum. He did his doctoral studies at Oxford University, and has research interests in metaphysics, Christology, Trinitarian theology, and the theology of grace; e-mail: tjwhiteop@gmail.com; ORCID: 00000003-2494-691X. 
subsisting in two natures. Linguistic tropes (idioms) assigned to Jesus of Nazareth either in virtue of his humanity - his nature as man - or in virtue of his divinity his nature as God - are attributed hypostatically only to one personal subject, that of the eternal Son and Word of the Father. So, for example, we say rightly that the Son of God personally suffered, died and was buried, in virtue of his human nature in which he was subject to these experiences, or more simply that God died by Roman crucifixion, here employing the nature-term "God" (a subject who has a divine nature) to denote the person of the Word who died a human death. Likewise, we may say that the human being Jesus can raise the dead by virtue of his omnipotent power, or that this man in particular is the author of the stars. The man in question is the person of the Son and therefore we rightly attribute to him the divine characteristics that are proper to the God of Israel, whom the Nicene creed denotes as one in being with the Father, and as the Creator "of all things visible and invisible." 1

In this essay I wish to consider the ontological dimensions of this form of linguistic designation of the mystery of the Incarnation, and more specifically to delineate various metaphysical implications of classical Christology. Can we speak truly of Christ the person of the Son as both true God and true man if we are incapable of positive philosophical and natural discourse concerning both the divine nature and human nature, that latter being the essence in virtue of which we are each human, and in virtue of which God who became human is one in nature with us? In what follows I will present a brief account of the inward form of the classical use of the communication of idioms in Neo-Chalcedonian Christology. Secondly, I will argue that the assignments we make of nature terms to Christ in virtue of his divinity and humanity respectively, though based in divine revelation specifically and associated with a central mystery of the faith, also require implicitly that we are naturally capable of thinking out philosophically what it means coherently to speak of the divine and human natures metaphysically. Were we unable to do this we would in turn be unable to think about the hypostatic union and the core mystery of Christianity in a constructive fashion. In a final section of the essay I will consider some of the consequences of the distinctively Catholic view of the Incarnation I am defending, in relation to metaphysics and consequently as an exemplification of the relationship between supernatural faith and natural knowledge, theology and philosophy, within the one cultural life of

Denz. 125. (All references to the magisterium of the Catholic Church in this essay, unless otherwise noted, are taken from Denzinger, Enchiridion symbolorum definitionum et declarationum de rebus fidei et morum [hereafter "Denz."], Forty-Third edition, ed. by P. Hünermann, R. Fastiggi, A. Nash, San Francisco 2010). 
the Church. ${ }^{2}$ I will argue that the intellectual heritage of divine-human synergy that fully acknowledges the ineffable transcendence and unique immanence of the Creator to creation in the incarnation has a philosophical correspondent in the tradition of Catholic perennial philosophy and that these two together form a the singular heritage of the Christian intellectual tradition, and is essential to health of the Church and human culture.

\section{THE BASIC VIEW: CHALCEDONIAN CHRISTOLOGY AND THE ONTOLOGY OF THE COMMUNICATION OF IDIOMS}

Single subject Christology is derived from and enshrined in the basic givens of the New Testament as apostolic teaching. Christ is one person subsisting in two natural modes of being. A case in point is to be found in Phil. 2:6-11, where the pre-existence of Christ is affirmed as the Son who, "though he was in the form of God," "took the form of a servant" and as man became obedient unto death, even so as to be exalted in the resurrection. The mystery of descent of the pre-existent Son into humanity and subsequent exaltation in resurrection culminates in the acknowledgement by the nations of his divine identity. He is given the name above every other name by the nations - "Lord" or "Yahweh" - who recognize in him the God of Israel denoted by the Tetragrammaton of Ex. 3:14-15. The fact that "every knee will bend" in adoration of him suggests that the prophecies of Is. 45:5-23, concerning the universal recognition of God by all gentile nations is coming to pass in the recognition of Jesus of Nazareth as Lord, that is to say as one who is both God and man, a man who was crucified and resurrected so as to reconcile the human race to the Father. ${ }^{3}$

2 For the purposes of this essay I am employing the term "metaphysics" to refer to the study of being, in classical philosophy and in the Catholic intellectual tradition. Employed in this sense the term has a slightly more narrow sense than "ontology" which can refer to the being of things themselves, whether it is apprehended and discussed philosophically and theologically. I also presume that philosophical metaphysics may and should be employed within and in the service of theology (sacra doctrina) in the service of the conceptual depictions of mysteries of the faith, as I shall mention below. I take this conceptual use of the term metaphysics to overlap significantly with the depiction of the term present in the papal encyclical Fides et ratio (1998) of Pope John Paul II.

3 See the pertinent analysis of the text on this point by R. Bauckham, God Crucified: Monotheism and Christology in the New Testament, Grand Rapids 1998, p. 44-54. Bauckham does not seek to derive a primal theology of the two natures of Christ from this text (an interpretative claim found in the patristic tradition but contested by many modern exegetes). However, he does argue convincingly that the Hebraic logic of the passage, which echoes the theology of Second Isaiah, co-simultaneously attributes to Jesus as a subject both the Lordship of the God of Israel and the human traits of the suffering servant. 
Evidently already in this primal confession of Christological faith we perceive the nucleus of the classical use of the communication of idioms as expressive in turn of the ontology of what would eventually be confessed in dogmatic conceptual form 400 years later at the Council of Chalcedon. Christ is a singular subject of Pauline ascription to whom are attributed characteristics associated both with God (signified here by the "form" of God, the name of YHWH, and being a subject of worship) and those of a human being (signified here by being the Suffering Servant, practicing intentional obedience, subjection to death as the separation of body and soul, physical resurrection and glorification). There is of course a correspondence between this linguistic pattern of ascription and the ontology it implies. Only if Christ is a single person who is both God and man, can formulations such as this one make sense. The person in question is pre-existent and divine in the Pauline logic, since "he" exists in union with the Father prior to his historical experience of being human, but the person in question is also the singular bearer of traits derived from each nature or "form" of being, as Lord and as man.

It is significant to note that the Council of Chalcedon specifically chose to denote and interpret the "forms" of Paul's Philippians 2:6-11 in distinctively ontological terms of nature or physis, having echoes in Hellenistic metaphysics. ${ }^{4}$ The impetus for this historically speaking is not simple and can be traced back in part to the influences of Athanasius, Gregory of Nazianzus' critique of Apollinarius, and the "letter of peace" written by John of Antioch in the wake of the Council of Ephesus. Nonetheless the proximate inspiration for the pronounced emergence of this pattern of interpretation was the famous Tome of Leo, his letter 28 to Flavian. Therein Leo does two things theologically that are of capital importance for the subsequent history of Christology. First, he interprets the "form of God" and the "form of a servant" in terms of the Latin notion of natura (or essentia) and in so doing also notes that the two natures are neither separate, nor confused, united yet distinct. ${ }^{5}$ This language is clearly ontological in implication and would enter into

4 Denz. 300: "[...] and it [i.e., the doctrine of the Church] resists those who imagine that there is mingling or admixture in the two natures of Christ and drives off those who foolishly believe that the 'form of a slave' taken by him from us is of heavenly or some other nature and it anathematizes those who invent the myth of two natures of the Lord before the union but imagine there was only one after the union."

5 Tome of Leo (letter 28 to Flavian), c. 3: "Without detriment therefore to the properties of either nature and substance which then came together in one person, majesty took on humility, strength weakness, eternity mortality: and for the paying off of the debt belonging to our condition inviolable nature was united with possible nature, so that, as suited the needs of our case, one and the same Mediator between God and men, the Man Christ Jesus, could both die with the one and not die with the other. Thus in the whole and perfect nature of true man was true God born, complete in what was His own, complete in what was ours. And by ours we mean what the Creator formed in us from the beginning and what He undertook to repair $[\ldots]$. 
the Council's formulations themselves, suggesting that God has become human without ceasing to be God and without abolishing, altering or in any way doing violence to what it is to be human. ${ }^{6}$ On the contrary, God is the most human of all of us. This idea suggests that there is not only no concurrence or rivalry of divine and human natures in Christ but in fact a kind of simultaneous plenitude of complementarity, of immanence and transcendence simultaneously. The more God is present in our human nature, even by personal union with our nature, the more naturally human we are, as is perceptible in Christ.

Second, Leo attributes activity to both natures, suggesting that each has its own integrity of operation.

For each "form" does the acts which belong to it, in communion with the other; the Word, that is, performing what belongs to the Word, and the flesh carrying out what belongs to the flesh; the one of these shines out in miracles, the other succumbs to injuries. $^{7}$

As we know, this was to be the most controversial aspect of the letter. Although it was itself incorporated into the acts of the council, there would be subsequent contestation of its contents precisely on this point. In the 6th Century Severus of

He took the form of a slave without stain of sin, increasing the human and not diminishing the divine: because that emptying of Himself whereby the Invisible made Himself visible and, Creator and Lord of all things though He be, wished to be a mortal, was the bending down of pity, not the failing of power. Accordingly He who while remaining in the form of God made man, was also made man in the form of a slave. For both natures retain their own proper character without loss: and as the form of God did not do away with the form of a slave, so the form of a slave did not impair the form of God."

c. 4: "In a new order, because being invisible in His own nature, He became visible in ours, and $\mathrm{He}$ whom nothing could contain was content to be contained: abiding before all time $\mathrm{He}$ began to be in time: the Lord of all things, He obscured His immeasurable majesty and took on Him the form of a servant: being God that cannot suffer, He did not disdain to be man that can, and, immortal as He is, to subject Himself to the laws of death. From the mother of the Lord was received nature, not faultiness: nor in the Lord Jesus Christ, born of the Virgin's womb, does the wonderfulness of His birth make His nature unlike ours. For He who is true God is also true man: and in this union there is no lie, since the humility of manhood and the loftiness of the Godhead both meet there." (trans. by C.L. Feltoe; ed. by P. Schaff, H. Wace, Nicene and Post-Nicene Fathers, vol. 12, Buffalo, NY 1895).

6 Council of Chalcedon, Denz. 302: "We confess that the one and the same Lord Jesus Christ, the only begotten Son, must be acknowledged in two natures (en duo phusesin), without confusion or change, without division or separation. The distinction between the natures was never abolished by their union but rather the character proper to each of the two natures was preserved as they came together in one Person and one hypostasis."

7 Leo the Great, Letter 28, c. 4. 
Antioch argued that the Tome's formulations were Nestorian, precisely because they denote that there are natures that operate as grammatical subjects, and therefore as distinct natural individuals or personal subjects. ${ }^{8}$ This line of thinking became common in monophysitism and monoerganism and would be condemned by the formal precisions of the Third Council of Constantinople where the teachings of Maximus the Confessor were in effect made normative. ${ }^{9}$ There we see that the distinct natural operations of deity and human, of God man, work in distinction and symphony, with instrumental subordination of the human actions to the divine operation.

From this settlement of orthodox Christology, a mature Christian vision of the communication of idioms developed. It is one we find present in Damascene's The Orthodox Faith, for example, a work translated into Latin in the middle ages. ${ }^{10}$

8 See Severus Ant., Ep. I ad Sergium, CSCO 120, 60, 33-61, 9, esp. in: A. Grillmeier, Christ in Christian Tradition, vol. 2, pt. 2, London 1995, p. 165. I have discussed this point in greater depth in Dyothelitism and the Instrumental Human Consciousness of Jesus, Pro Ecclesia 17 (2008), p. 396-422.

9 Referring back to Leo's Tome as a traditional auctoritas, the council affirms "two natural principles of action in the same Jesus Christ," and cites in this respect Leo's statement from the Tome in Greek so as to make clear that "each form does (morphe energei)" that which is proper to it, in concord with the other. In addition, the document goes on to state that "each of the two nature wills and performs what is proper to it in communion with the other. Thus, we glory in proclaiming two natural wills and actions concurring together for the salvation of the human race." (Denz. 553, 558).

10 See in particular On the Orthodox Faith, III, cc. 4-19, trans. S.D.F. Salmond, Nicene and Post-Nicene Fathers, Oxford 1899. See Aquinas, Summa Theologiae, III, c. 16 on the communication of idioms, and q. 19, a. 1 in his critique of Severus and his defense of dyotheletism. Damascene provides a clear analysis of the traditional use of the communication of idioms in $O n$ the Orthodox Faith, III, c. 4. "When, then, we speak of His divinity we do not ascribe to it the properties of humanity. For we do not say that His divinity is subject to passion or created. Nor, again, do we predicate of His flesh or of His humanity the properties of divinity: for we do not say that His flesh or His humanity is uncreated. But when we speak of His subsistence, whether we give it a name implying both natures, or one that refers to only one of them, we still attribute to it the properties of both natures. For Christ, which name implies both natures, is spoken of as at once God and man, created and uncreated, subject to suffering and incapable of suffering: and when He is named Son of God and God, in reference to only one of His natures, He still keeps the properties of the co-existing nature, that is, the flesh, being spoken of as God who suffers, and as the Lord of Glory crucified 1 Corinthians 2:8, not in respect of His being God but in respect of His being at the same time man. Likewise also when He is called Man and Son of Man, He still keeps the properties and glories of the divine nature, a child before the ages, and man who knew no beginning; it is not, however, as child or man but as God that He is before the ages, and became a child in the end [of the ages]. And this is the manner of the mutual communication [of idioms]. [...] Accordingly we can say of Christ: 'This our God was seen upon the earth and lived among men,' and 'This man is uncreated and [...] uncircumscribed [i.e., in virtue of his divinity].", 
The perspective of Damascene was in turn self-consciously adopted and re-articulated by Thomas Aquinas in the Summa Theologiae, Tertia pars. Aquinas effectively notes four rules that govern the right application of the communication of idioms, each of which has an ontological correspondent, with significant for our consideration of philosophical metaphysics. ${ }^{11}$

First, Aquinas notes that all attributes of divine nature and of the human nature of Christ pertain to the single personal subject of the incarnate Word. ${ }^{12}$ That is to say, whether we speak of the eternal generation of the Son or his human birth in time as man, we attribute such characteristics only to Jesus Christ, the eternal Son of the Father. He was born before all ages of the Father and born in time of the Virgin Mary. He is the author of creation and the giver of eternal life, but is also subject to human torture, suffering and death.

Second, the attributes of the two natures are not rightly predicated of each other, and should not be confused. They remain ontologically distinct. ${ }^{13}$ The divine nature of Christ is eternal not temporal, immutable not subject to alteration, impassible not subject to suffering, all knowing, not subject to nescience. The human nature of Christ is present in time and place not subject to omnipresence, finite not subject to infinity, temporal not subject to conditions of eternal pre-existence. The human nature of Jesus then is not omnipresent

11 See the study of Aquinas' use of Damascene on this point by C.L. Barnes, Christ's Two Wills in Scholastic Thought: The Christology of Aquinas and its Historical Context, Toronto 2015. In ST ІІ, q. 19, a. 1, when treating of Leo and Severus, Aquinas follows Damascene's interpretation of the Third Council of Chalcedon found in On the Orthodox Faith, III, c. 16. He then proceeds to defend Leo's Tome against its monergenist critics (corp. and ad 4): "The human nature has its proper operation distinct from the divine and conversely. Nevertheless, the divine nature makes use of the operation of the human nature, as of the operation of its instrument [...]. Being and operation belong to the person by reason of the nature; yet in a different manner. For being belongs to the very constitution of the person, and in this respect it has the nature of a term; consequently, unity of person requires unity of the complete and personal being. But operation is an effect of the person by reason of a form or nature. Hence plurality of operations is not incompatible with personal unity." (All citations from the ST in this essay are taken from the Dominican English Province translation, Summa Theologica, New York 1947).

12 ST III, q. 16, a. 4 and ad 1: "since there is one hypostasis of both natures, the same hypostasis is signified by the name of either nature. Thus whether we say 'man' or 'God,' the hypostasis of Divine and human nature is signified. And hence, of the Man may be said what belongs to the Divine Nature, as of a hypostasis of the Divine Nature; and of God may be said what belongs to the human nature, as of a hypostasis of human nature [...]. It is impossible for contraries to be predicated of the same in the same respects, but nothing prevents their being predicated of the same in different aspects. And thus contraries are predicated of Christ, not in the same, but in different natures."

13 An idea enunciated clearly by Damascene in On the Orthodox Faith, III, c. 4, cited above. 
or pre-existent or eternal, while the divine nature is not a historically contingent process, subject to generation, or redetermined in identity through impact of

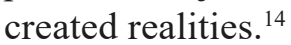

Third, all nature terms (divine or human) can be employed grammatically as subject terms if and only if they denote the personal subject, considered under the aspect of a nature. For example, we can rightly say that "God gestated in the womb of the Virgin," "God was born in poverty," "God suffered personally on the Cross," or "God truly died on the Cross." These are all necessary statements and are orthodox because the term God is a nature term denoted of a specific person, the Second Person of the Son. This means it is not true to say "the divine nature was born, suffered, died, etc." or "the Father or the Holy Spirit suffered," but only "the Son who is God and man was born, suffered and died, as a divine person who is truly human like us," and therefore "God truly was born, suffered and died." Likewise we may say that "this man created the world," indicating Jesus Christ, without implying that his human nature was an instrument of the creation, or we may say that "God was obedient in order to save us" without implying that his human obedience is constitutive of his eternal generation from the Father as the eternal Son. ${ }^{15}$

Fourth, one may ascribe actions to the natures of the Jesus Christ as such so long as one is clear that this does not imply that these natures are individual

14 ST III, q. 16, a. 5, corp. and ad 1, and ad 3: "What belongs to one cannot be said of another, unless they are both the same; thus 'risible' can be predicated only of man. Now in the mystery of Incarnation the Divine and human natures are not the same; but the hypostasis of the two natures is the same. And hence what belongs to one nature cannot be predicated of the other if they are taken in the abstract [...]. [T] hus we say that the Son of God is born, yet we do not say that the Divine Nature is born; as was said in ST I, q. 39, a. 5. So, too, in the mystery of Incarnation we say that the Son of God suffered, yet we do not say that the Divine Nature suffered [...]. What belongs to the Divine Nature is predicated of the human nature - not, indeed, as it belongs essentially to the Divine Nature, but as it is participated by the human nature. Hence, whatever cannot be participated by the human nature (as to be uncreated and omnipotent), is nowise predicated of the human nature. But the Divine Nature received nothing by participation from the human nature; and hence what belongs to the human nature can nowise be predicated of the Divine Nature."

15 ST III, q. 16, a. 5: "Now concrete words stand for the hypostasis of the nature; and hence of concrete words we may predicate indifferently what belongs to either nature - whether the word of which they are predicated refers to one nature, as the word 'Christ,' by which is signified 'both the Godhead anointing and the manhood anointed"; or to the Divine Nature alone, as this word 'God' or 'the Son of God'; or to the manhood alone, as this word 'Man' or 'Jesus.' Hence Pope Leo says (Letter 74): 'It is of no consequence from what substance we name Christ; because since the unity of person remains inseparably, one and the same is altogether Son of Man by His flesh, and altogether Son of God by the Godhead which He has with the Father."' See also ST III, q 16, aa. 7 and 9. 
persons ${ }^{16}$ We may say for example, as Leo does, that the "divinity performs miracles," while "the humanity suffers," because he indicates that the operations of the two natures are of the one person of the Son incarnate. This does not mean that the divinity is a personal subject distinct from the humanity but only that we abstractly signify the two natures by referring to the operations that are proper to each in the one person. It is in virtue of his divinity that Christ has the active potency to perform miracles and in virtue of his humanity that he has the capacity to suffer. Meanwhile if we say that "the infinite lay in a crib" or "the humanity breathed its last on the cross," we refer to the nature substantively rather than operationally but we do so by prescribing implicitly these substantive features of nature to the one personal subject of the Word. "He who is infinite lay in a crib," "He who is human died on the cross."

It should be noted that these four principles help us delineate the shape of a mystery, in human language. They are not meant to render the mystery of the incarnation, life, suffering and death and resurrection of Christ fully transparent to human reason, nor do they simply leave these features of his existence unintelligible or opaque. They serve rather to help us identify the inward region and boundaries of the mystery of the faith and exclude erroneous or counterfeit formulations. It seems to me in turn we can identify three important ontological features that emerge from this inscape of mystery, rightly to be thought of as Christological truths, that in turn also have implications for philosophical metaphysics (without being reducible to the latter). I will return to these below.

The first ontological feature of the mystery pertains to the person of the Son: he can begin to subsist as man (by homonization in the womb of the Virgin Mary) without ceasing to be truly God. Consequently, precisely as one who is God personally he can also become subject to all that is human, including birth, suffering and death, which he truly experiences personally without ceasing to be

16 ST III, q. 19, a 1, ad 3 and ad 5: "To operate belongs to a subsisting hypostasis; in accordance, however, with the form and nature from which the operation receives its species. Hence from the diversity of forms or natures spring the divers species of operations, but from the unity of hypostasis springs the numerical unity as regards the operation of the species: thus fire has two operations specifically different, namely, to illuminate and to heat, from the difference of light and heat, and yet the illumination of the fire that illuminates at one and the same time is numerically one. So, likewise, in Christ there are necessarily two specifically different operations by reason of His two natures; nevertheless, each of the operations at one and the same time is numerically one, as one walking and one healing [...]. The proper work of the Divine operation is different from the proper work of the human operation. Thus to heal a leper is a proper work of the Divine operation, but to touch him is the proper work of the human operation. Now both these operations concur in one work, inasmuch as one nature acts in union with the other." 
"immutably, impassibly" divine and one of the Holy Trinity. There are various soteriologicalaspects to this mysterious truth. For example, God truly shows his divine solidarity with us by freely identifying with our human limitations, and he can unite his ineffable, perfect divinity and saving power to us even in worst darkness of our human suffering. Everything we have as human becomes his so that everything he has as God can become ours, even in the most trying moments of our condition. Behind this soteriological claim we confront the mystery of God's gratuitous freedom: it is grounded in his mysterious activity and eternal identity. The mystery from before the foundations of the world is personal, good, wise, and loving.

Second, the two natures of Christ are not confused or mixed, but they also are not competitive rivals or mutually exclusive. Christ does not have to cease being God in order to be human or take on a truncated or artificial human nature in order to be God. ${ }^{17}$ There are profound metaphysical implications to this claim. God is not a rival to his creation, seemingly because God is in no way exterior to his creation as Creator, but is more intimate to created being than

17 Consider in this respect the alternative views on the communication of idioms by Sergius Bulgakov in The Lamb of God, trans. B. Jakim, Grand Rapids 2008. Bulgakov develops a coherent critique of John Damascene's use of the communication of idioms, based on the idea that the latter permits the divine essence of Christ to influence the human essence (through divinizing grace) but does not understand the divine essence to conform to or become subject to alteration by the human essence as an ontological condition of the incarnation (see especially 209-210, 258-259). The proposed alternative of Bulgakov (which has its proximate origins in Gottlieb Thomasius and which resembles proposals of Karl Barth that we will examine below) is that the divine essence freely accommodates itself kenotically to the lowliness of the human state of Christ by adopting human characteristics of temporality and suffering into the godhead (the divine nature) as a condition of possibility for the mystery of the incarnation. Interesting, in the start of the book (pp. 2-19) Bulgakov begins his Christology with a defense of the Christological ontology of Apollinarius of Laodicia, who he claims was the first truly to acknowledge the impossibility of the co-existence of two fully autonomous principles of nature (divine and human) in Christ co-existing in unity, without the problem emerging of rivalry. Whereas Apollinarius ultimately resolved the problem problematically by denying the complete humanity of Christ, Bulgakov will ultimately attempt to resolve the problem otherwise by positing the self-delimitation and kenotic dynamism of the divinity of Christ. But whether one chooses one solution or the other (Apollinarius or Bulgakov) the problem is found in the fundamental premise (as elaborated by Bulgakov) of a necessary rivalry of natures unable to co-exist in a unity without the self-delimitation of one or the other. It is precisely this kind of erroneous principle (perhaps derivative remotely from the nominalist heritage) that Damascene avoids and rejects from the start. Far from being a hindrance to a dynamic Chrsitology of divinization and a residue of Byzantine scholasticism that "did not go far enough," Damascene is a theologian who points us in the right direction, precisely on this point in question. 
it is to itself, or most interior to the effect of the Creation (the esse commune of created being) without being identical with that creation as such..$^{18}$ This means that God can "step out onto the stage" of creation and enter the drama of created history without either ceasing to be God or doing violence to human nature. As noted above, the traditional Christian claim is that no one is more human than Christ, who is also truly God. ${ }^{19}$ Furthermore, the human nature of Jesus can be subordinate to and the instrument of his divine person (the humanity of the Word) without in anyway being diminished as human. On the contrary, the human nature of Jesus, his human actions of knowledge and love as man, are now expressive of his personal identity as God, the Son, who manifests his eternal life and presence in and through his epitomal human actions, words, gestures, teachings, sufferings and miracles. ${ }^{20}$ It is God the Son who shines forth radiantly in the most human life of Jesus, from the child in the crib to the crucified of Golgotha.

Third, we can infer from the third and fourth of our rules of predication above an ontological mystery first identified by the Cappadocian fathers. All works of the divine persons are works conducted through the medium of a nature.

18 See on this point, ST I, q. 4, a. 2, and the study of Martin Bieler, "Analogia entis" as an expression of love according to Ferdinand Ulrich, in: The Analogy of Being: Invention of the Antichrist or the Wisdom of God?, ed. Th.J. White, Grand Rapids, MI 2011, p. 314-37.

19 A point underlined in the Second Vatican Council, in Gaudium et spes, 22 and 45. In Chapter 22 where it is said that Christ is "perfect man," appeal is made in the footnote precisely to Chalcedonian Christology. (Denz. 4322): "Council of Constantinople II (553), can. 7: '[...] without either the Word being transformed into the nature of the flesh or the flesh being translated into the nature of the Word,' cf. also Council of Constantinople III (681): '[...] for just as his most holy and immaculate flesh, animated by his soul, has not been destroyed by being divinized but remained in its state and kind'. Cf. Council of Chalcedon (451): '[the same Lord Jesus Christ] [...] must be acknowledged in two natures, without confusion or change, without division or separation.' Perceiving the conceptual unity and organic development of thought across time expressed by these four Councils of the Catholic Church, one is reminded of John Henry Newman's notes pertaining to the identification of genuine development of doctrine in the Church. In fact all seven notes would apply readily to this development from the affirmation of the two natures of Christ (Chalcedon) to the underscoring of the immutability and perfection of each nature (Constantinople II) to the affirmation of the two activities and wills (Constantinople III), to the emphasis on the reality, integrity and exemplary perfection of the Lord's humanity (Vatican II). We can perceive here preservation of type, continuity of principles, assimilative power, logical sequence, anticipation of the future developments in the early principles, conservationist action on the past principles by later affirmations, and chronic vigor. See An Essay on the Development of Christian Doctrine, London 1909, esp. chap. 5.

20 I have explored this idea further in The Incarnate Lord, A Thomistic Study in Christology, Washington, D.C. 2015, chap. 1. 
All works of a nature are works conducted by a personal subject. ${ }^{21}$ The one is a principle "from which" while the other is a principle "through which." Persons are those "from whom" and natures are that "through which." The Father, Son and Holy Spirit operate by virtue of or in and through the medium of their shared divine nature and life, as God, while the Son alone operates also by virtue of or in and through the medium of his human life as man. There are two significant features to this third idea. First, evidently, from a Christian and therefore Trinitarian point of view, all things are ultimately personal in origin. The divine nature that has given rise to all things and that providently governs human history in view of salvation is a reality that is personal in nature. The universe exists from persons and in view of personal existence as the summit of created being, our personal life, along with that of the angels, created meaningfully in view of communion with God in Christ. Second, in personal realities, all nature terms must be interpreted in a way that is in conformity with but also not in opposition to personal identity, and vice versa. Negatively speaking it is a great mistake to oppose natural identity (being human or being a biological animal, for example) with personal identity, as if one must either advocate for an ontology of persons or an ontology of natures. One way to make this error is to claim that a serious study of human nature does away with personhood and personal dignity as a mere folklore concepts from pre-modern culture. The other way to do so is to claim that the acknowledgement of human personhood and personal freedom requires that we delimit or deny the reality of nature as a normative concept for free human action or thought, as if the personal agent could invent or at least mutate his nature in a plastic fashion in the service of his personal creative freedom or will to power. In reality, all personal acts of knowledge and love are eminently natural acts stemming from the natural principles of human

${ }^{21}$ In fact, the principle that "'a nature is never found except within a hypostasis" was employed by anti-Chalcedonian monophysites of the sixth century in order to argue for the singularity of the nature in Christ. Dyophysites responded by adopting the same principle and reinterpreting it in light of the distinction between the operation of $a$. person and operation through (or by means of) a nature. This way of thinking has its origins in earlier Trinitarian debate. The distinction between the nature common to a plurality of persons and the particular personal subject in which this nature exists originates with Basil in his Epistle to Terentius (PG 32, 798 A). It was developed Christologically in the context of dyothelete disputes by John the Grammarian and Leontius of Byzantium. (See, for example, Contra Nestorianos et Euthychianos, PG 86, 1280 A, by the latter.) John Damascene notes that the principle is essential to a right understanding of the practice of the communication of idioms as pertaining to the incarnation, in: On the Orthodox Faith, III, c. 4, 5, 9, 11, and 12. Aquinas's own thought offers a close parallel to Damascene in ST I, q. 39, a. 5, IП, q. 3, a. 4, ad 1 and III, q. 19, a. 1: nature is the principle through which a subject or hypostasis acts, but it is always the subject who acts. 
knowledge and free will. ${ }^{22}$ This is true in Christ's own human knowledge and freedom, which are reflective in turn of his uncreated divine life, his eternal natural wisdom and love as God.

\section{THE NATURAL GROUNDS OF MYSTERY: THE CHRISTOLOGI- CAL PRESUPPOSITION OF A PHILOSOPHICAL METAPHYSICS}

In light of the ontology implied by the classical use of the communication of idioms, we rightly should affirm that Chalcedonian Christology (and therefore a fortiori all Catholic theology) presupposes and needs to make use of various principles of classical metaphysics. Why is this the case and in what sense? Here I succinctly will demarcate basic principles contained implicitly within the Christology elaborated above, while still maintaining that philosophical reflection is formally distinct as such from theological or dogmatic reflection on the revelation of Christ. ${ }^{23}$

The first principle to be noted is that the identification of the form of metaphysical realism incumbent upon Catholic theologians for a right exercise of their own science can appear only consequent to and in a sense from within theology as such, and yet as a formally distinct subject area. Here I mean simply that it is antecedently probable - in a world affected by the wounds of ignorance and human self-will - that in pre-Christian cultures, the natural human intellect may not take account of or realize all of its innate possibilities,

22 See the Thomistic argument to this effect offered by J. Maritain in his Court Traité de l'Existence et de l'Existant, Oeuvres Complètes, vol. 9, Fribourg-Paris 1990, originally published in 1947 in response to the voluntarist ontology of Jean Paul Sarte.

23 Erich Przywara's characterization of the "analogia entis" as the fundamental form of Catholic theology seems to me to run the risk of identifying properly philosophical objects of reflection with those pertaining to divine revelation, so that theology is overly determined "from the bottom up" by metaphysical reflection culminating in Christology (one might think in this respect of Rahner's transcendental anthropology) or philosophical reflection is overly determined "from the top down" as essentially a dimension of Christology (analogous to Barth's Christological ontology). On this idea, see Analogia Entis; Metaphysics: Original Structure and Universal Rhythm, trans. by J. Betz, D.B. Hart, Grand Rapids 2014, Part II, chap. 2, "The Scope of Analogy as a Fundamental Catholic Form," pp. 348-399. Balthasar identifies this problem in Przywara's thought, rightly it seems to me. See his critical remarks in Theo-Logic, II: The Truth of God, trans. by A. Walker, San Francisco 2004, pp. 94-95, n. 16, and the logically congruent observations on p. 273, n. 109. My own views on the distinction and interaction of the "analogia fidei" and the "analogia entis" are akin to those of G. Söhngen, The Analogy of Faith: Likeness to God from Faith Alone?, Pro Ecclesia 21,1 (2012), p. 56-76, and The Analogy of Faith: Unity in the Science of Faith, Pro Ecclesia 21,2 (2012), p. 169-94, trans. by K. Oakes. 
or may have doubt about the latter. To affirm that there is such a thing as philosophical metaphysics follows from the distinction between nature and grace, and between natural knowledge and the revelation obtained in virtue of the grace of faith. The affirmation of natural knowledge is the necessary corollary to a theology of grace and revelation. This does not entail however that one must hold that a pristine, deeply developed natural metaphysical reflection must precede the exploration of the ontology of Christ in time either for any individual or for human culture more generally. Such may be the case in fact, but my argument here does not require that it be so. As a matter of hypothesis, one might posit that all Christian philosophy develops only after Christ, but even if this is the case, it still develops as philosophy, in the service of faith, and as logically entailed by the predications we make to Christ of the divine and human natures.

The second important principle to observe is that when we speak of the divine nature or the human nature of Christ, we must qualify that we are speaking of a theological mystery, not a mere truth of philosophical reasoning. Even if we do know something of what human nature is and how to speak rightly of the divine nature philosophically in distinction from or prescinding from divine revelation as such, the divine and human natures of Christ are formally mysteries approached primarily with the help of divine revelation. The nature in virtue of which Christ is one with the Father and the Holy Spirit pertains to the essence of the Trinity. The essence in virtue of which he is one with us designates our human nature redeemed and sanctified in the New Adam, subject to atoning death and eschatological exaltation. This is why Gaudium et spes para. 22 rightly notes that the mystery of what it means to be human is only ultimately resolvable by reference to Christ, in whom are present the plenitude of grace and the perfection of human nature by and within the life of that grace. ${ }^{24}$

Having provided these two primary warnings against a naïve form of theological rationalism, we can now proceed to a third and more essential point. The mysteries of Christ's divine nature and human nature are literally unthinkable or conceptually inaccessible for us unless we are also capable of some form of natural reflection regarding the nature of God the Creator (conceived by way of analogy), as well regarding the structure of human nature (univocally denoted in

24 Gaudium et spes, para. 22 (Denz. 4322): "The truth is that only in the mystery of the incarnate Word does the mystery of man take on light. For Adam, the first man, was a figure of Him Who was to come, namely Christ the Lord. Christ, the final Adam, by the revelation of the mystery of the Father and His love, fully reveals man to man himself and makes his supreme calling clear." What is at stake is clearly the supernatural truth regarding the human being, revealed in the person of Christ and his human nature. 
universal fashion). The reasons for this should be obvious. Let us consider the divine and human natures in turn..$^{25}$

If the human being cannot think naturally about the existence of God and the nature of God as creator (however indirectly, apophatically or analogically) then the very idea of the incarnation, as proposed in Chalcedonian terms, is literally unthinkable. This is the case because the very idea of Jesus as a personal subject possessing the divine nature and having its "attributes" predicated of him would be thoroughly unintelligible. Even if the divine nature of the Son is a mystery of faith, one possessed in common with the Father and the Spirit and revealed to us supernaturally, its reception in human thought requires an analogue concept drawn from philosophical understanding that allows the human intellect to orient itself toward God. Were this not the case, the judgment of faith that "Christ possesses divine nature" or "is God" would stand completely outside the ambit of the natural capacities and range of human knowing. In this case, the gift of faith would be so extrinsic to the human intellect as to be literally inassimilable. Positive knowledge of the divine nature is a natural requirement if the human person is to be in "obediential potency" to the gift of grace that permits him to know and affirm that Christ is God. ${ }^{26}$ This means that only if there is a metaphysical range of knowledge that can affirm the existence of God coherently and demonstrably as a truth of reason is it possible to develop a reasoned account of the intellectual possibility of faith, and in turn also an intellectually self-conscious dogmatic theology. Dogmatic reflection on Christ without metaphysics would be in this respect an insincere act of the mind by which the activity of faith would orient the mind towards an end purely extrinsic to any conditions of human thought, leaving the latter (human reason) immanent to itself without intrinsic reference to divine truth, even despite the presence of the grace of faith.

25 For the sake of what follows below, I am referring to natural knowledge of God as "analogical" in the broad sense so as to indicate that no species or genus of category we use for a created entity or feature of being can be predicated of God is precisely the same sense, without qualification. Presumably this kind of definition permits one to include, for the sake of argument, various Scotistic forms of predication, that are not the subject of criticism or consideration in this essay. Similarly, when speaking of the "univocal" predication of human nature to all human beings, I mean to suggest simply that we can and must denote all human beings as being essentially the same kind of reality, and not members of distinct species, independently of their property characteristics such as age, race, or sexuality.

26 In employing the notion of obediential potency I'm suggesting that we have no natural intellectual inclination to know of the Trinity as such, and its essential unity, but that we do have a natural inclination to think about God analogically, and about the divine nature, that can be elevated by grace so as to be placed in the service of reflection on the mystery of Trinitarian unity as such. 
To give a precision to this notion we can clarify what must be the case for there to be a natural capacity for faith in the mind, without there being a purely rational derivation of the object or act of supernatural faith (epistemological Pelagianism). On the one hand there must be a specification of human thinking by conceptual reason and contemplative judgment that allows human beings to think about God the Creator in truth by means of natural or philosophical reflection. This specification is not identical with that of supernatural faith, which orients human intelligence toward the awareness and understanding of God as Holy Trinity, and eventually may terminate in the beatific vision of God, all of which is made possible only by grace. But the former natural specification is taken up into, preserved and made use of within the activity of faith, even if it can in no way produce or initiate the latter supernatural act. Under grace and within grace, however, the natural capacity to think about God is taken up into the act of faith and moved within this act toward God, as known both supernaturally and naturally. ${ }^{27}$ The reason that the natural pre-disposition is essential is not because it causes the faith but because without it faith would be so alien as to be violent to the human intellect and nature would be unable to move itself under grace and within grace toward God. ${ }^{28}$ The natural and supernatural specifications of the human intellect remain distinguishable but in no way extrinsic to one another. They function in harmony, hierarchical coordination and instrumental subordination. The revelation of God addresses the natural human desire for perfect knowledge of God (the desire to see God), but elevates this inclination of nature to a higher plane and provides it with new life and dynamic specification. ${ }^{29}$

Likewise, the basic theological commitment to Chalcedonian Christology requires a metaphysics of human nature that permits us to identify a structure of human nature attributed univocally to all human beings. That is to say, there is an essence of human nature, one adopted by God in the incarnation, that is present universally by way of identity of kind in all human beings. Note at least two reasons this must be the case, for theological motives. First, if we cannot in any way

27 This is why there will always be a De Deo Uno treatise of divine attributes or names within and for a De Deo Trino, in no matter what age of the world or in whatever philosophical register, be it Neoplatonic, Aristotelian-scholastic, Kantian, Hegelian, Analytic, etc.

28 Parallels exist in the world of the will. Only if there is a natural desire for God distinct from the grace-inspired inclination toward God by way of infused hope and charity can the latter grace be received into the human person in an immanent and humane way, and yet still be a gratuitous grace. See my argument to this effect in: Th.J. White, Imperfect Happiness and the Final End of Man: Thomas Aquinas and the Paradigm of Nature-Grace Orthodoxy, The Thomist 78,2 (2014), p. 247-289.

29 See on this point, Aquinas, ST I-II, q. 62, aa. 1-3. 
identify the essential nature of man in its universal specification making use of the instruments of natural human reason, then we also cannot understand coherently what it means to say that God became a human being having a human nature in solidarity and plenary identification with us. In this were the case, the universal soteriological significance of the incarnation would be eclipsed. What does it even mean to say that God became truly human if there is no human race (a group of entities that share a common nature and destiny)? A merely extrinsic Christological designation of human nature (cf. Karl Barth) is not possible, because we would not be able naturally to identify what a human being is as distinct from something having mere accord of phenomenological appearances. ${ }^{30}$ Christ's divine "attempt" to draw the so called human race into unity would be ineffective necessarily if we cannot ourselves even recognize what human nature is, even after redemption. Grace can heal or sharpen the capacities of natural intellect to identify the essence of man and the Church's philosophical and natural law traditions serve to do just this, but they can only do so because there already exists in each human being a pre-disposition or natural capacity to think realistically about human identity in its essential constituents.

Second, on this front, we cannot understand the perfection of Christ's human nature in its modal realization under grace, and internal to the hypostatic union, if we cannot understand the essence of man as such. For example, we cannot understand the mode of perfection present in Christ's human obedience, in love, humility and sinlessness, if we cannot understand something of human reason and freedom more generally, human obedience, and the virtues. Likewise, we cannot appreciate the supernatural mystery of Christ's suffering out of love for the human race in the crucifixion if we cannot understand something of the philosophical conundrum of human suffering, and the distinctions of body and soul, as well as the enigma of death and the natural evil it represents. Examples could be multiplied but the principal point is clear. Catholic theology must be committed to a metaphysical realism concerning the nature of the human being, as a presupposition for any rigorous commitment to Christological orthodoxy.

30 Barth famously argues that we can only accede to a genuine knowledge of human nature in light of Christ, and from the perspective of divine revelation. Taken to its logical conclusion, however, this position would suggest that the very notion of "nature" or "human nature" is so alien to us intellectually (at least in our fallen state) that it cannot be employed in any meaningful way. Insofar as we do think actively in conceptual forms, even in response to Christ and under the influences of his grace, we must make use of some conceptual forms of knowledge to orient ourselves toward the objects of faith, which is only possible if there is some way to identify them (in part) under naturally intelligible idioms, as when we say, for example, that Jesus of Nazareth was "a man" or "a human being" having the same identity as us in the order of nature. 
A final philosophical principle concerns the philosophical notion of personhood. Evidently, Christianity depends upon and in turn interprets the basic claim of the Torah that the human being is made in the image of God. This view contains several essential components. There is a hierarchy of beings, where non-living things exist in some sense not only for God, but for living things, and this in turn can be said of living things in relation to the human community. ${ }^{31}$ The latter is differentiated in a specific way by its immaterial powers of intelligence and deliberating love or free will. These features of personal existence emerge from the spiritual soul as the form of the human body. The existence of the spiritual soul is indeed a truth of human reason, also maintained dogmatically by the teaching of the Catholic Church, based on a discerning interpretation of the givens of scriptural revelation. ${ }^{32}$ It is because we are spiritual animals that we are persons and have in common with God and the angelic community the features of existence that make personal communion possible with other spiritual realities. ${ }^{33}$

This means that there is a teleological end to human personhood that must also be maintained by Catholic theology for Christological purposes. Human beings are immanently inclined by their spiritual powers toward the pursuit of the knowledge of the truth and the desire for happiness by way of love of the authentic good. It bears worth mentioning in keeping with our theme, that Christ cannot be the exemplar and indeed the savior of human existence in any meaningful way if he as man in his human soul does not teach us and realize in our human nature these features of human existence. Christ is a man who knows and expresses the most important truths of all of human history and who manifests in the redemptive event of his own human life the plenary realization of human happiness: the possession of God by the beatific vision and by the fullness of charity. This is of course a mystery of grace, but if human beings are not capable of any natural philosophical understanding of the spiritual vocation of the intellect of man for the truth and for the possession of personal happiness in God, then they are also incapable of seeing the inner intelligibility of the gift of salvation realized in Christ. ${ }^{34}$

31 See Aquinas' argument to this effect in Summa Contra Gentiles III, c. 22. (Summa Contra Gentiles, III, trans. by V. Bourke, New York 1955-1957).

32 Catechism of the Catholic Church, para. 366: "The Church teaches that every spiritual soul is created immediately by God - it is not "produced" by the parents - and also that it is immortal: it does not perish when it separates from the body at death, and it will be reunited with the body at the final Resurrection." Unambiguous authoritative clarifications on this point are found, for example, in Paul VI, Credo of the People of God; Pius XII, Humani generis, and Lateran Council V (1513).

33 The helpful Thomistic study of this topic by F. Daguet, Finis Omnium Ecclesia; Théologie du Dessein Divin chez Thomas D'Aquin, Paris 2003.

34 See Aquinas' arguments regarding basic human inclinations in ST I-II, q. 94, a. 2. 
This claim does not imply that one must have philosophical understanding of any developed kind as a propaedeutic to acknowledging salvation in Christ but rather the latter: reception of the mystery of Christ in grace addresses, stimulates, rejuvenates, heals and elevates the human capacity to seek the universal truth and to seek authentic and profound happiness in God.

\section{CONCLUSION: CHRISTOLOGICAL COSMOPOLITANISM AND THE "METAPHYSICAL APOSTOLATE" OF THE CHURCH}

We can conclude this essay with two brief observations, one regarding what the vision it promotes implicitly excludes and one concerning the open horizon of what it can include. The first of these topics is easy to treat by noting positions of either theology or philosophical metaphysics that contradict the basic principles noted above. We can exclude either a theological totalism that refuses in principle the possibility of a perennial metaphysics for theological reasons (represented in sophisticated fashion by Barth), or a rationalist evidentialism that might seek to demonstrate the truths and inward content of the mysteries of Christianity by recourse to principles of philosophical reason (cf. features of the project of Richard Swinburne).

The claim made above regarding philosophical knowledge of both divine and human natures remain in some fundamental incompatibility with the axiomatic speculative agnosticism of Kant, rearticulated in creative fashion by Heidegger in his later work. Arguably it is also opposed to elements of Hegel's ontology insofar as the latter identifies the developmental life and evolution of God with the intra-created processes of history. The philosophical notion of a universally identifiable human nature also stands in contrast to ambient forms of nominalism that arise most typically in modern naturalism, and which tends to see human identity as a mere bundle-configuration of atomic or cellular traits, or which interprets human identity only by reference to genetic codes and therefore interprets human nature ultimately in materialistic and quasi-individualistic terms. Mainstream contemporary naturalism is also opposed to the principle regarding personhood. Both the idea of a hierarchy of being within nature of grades of being and of human beings as spiritual animals finds no place within much of contemporary analytic philosophy when the latter seeks to explain human identity merely by reference to biological findings of the modern sciences and the material constitution of human mental activity. In such a world, human personal dignity and trinitarian mystery both become increasingly unintelligible. To speak of Christ in our own age then is also to speak metaphysically and incisively of God and human nature. 
What does this Catholic advocacy of metaphysics permit or encourage? Thomism is of course a usual suspect in this regard. Aquinas' metaphysics of natural realities, his analogical discourse concerning the incomprehensible God, his commitment to a profound investigation of the nature of the human person, and his hylomorphism, as well as his metaphysics of creation and the real distinction of esse and essentia: all of this can be seen as a vast expression of spiritually enlightened Christian philosophy developed from within the folds of sacra doctrina. But this remains only one among many possibilities, classical and modern, from Irenaeus, Augustine and Maximus to Bonaventure, Aquinas and Scotus, to Pascal, Newman, Scheeben, and Ratzinger. In fact, just to the extent that all of these major figures think from within the form of understanding under consideration, they also speak to one another, and therefore to those who take inspiration intellectually from their pluriform heritage within the Church.

Reflection on Christology and philosophical reflection on metaphysics both take place within a singular history, in which they are integrated in a singular (multivalent) Christian culture of faith and reason. This life of reflection on Christological ontology occurs for the Church first and foremost to clarify her confession of faith and in order to communicate it evangelically. But by that very measure it also takes place for the world at large, since it seeks to explain reality philosophically in light of Christ and in relation to God's existence among us as a human being. If the incarnation has a universal horizon of meaning and intelligibility (so that all things are explained in light of Christ) then there must also be a way in the Church and in culture at large to think about all that is, philosophically in light of God, and to think about the place of human nature within the larger framework of the existence of the world God has made. Where this impossible (on the natural level) we would be incapable of "taking every thought captive to obey Christ" (2 Cor. 10:5) on the supernatural level. For these same reasons, the universal proclamation of the mystery of Christ requires not only a theoretical Christology but also a metaphysical apostolate as a dimension of Christology. In concrete history the stimulus may often come first from the side of the grace of the Holy Spirit, but to live this grace in an integral fashion, the Church must learn to confess Christ as both true God and true man as the basic truth of all reality, and in every generation. In doing so, she also learns to speak of God and man naturally and philosophically, in every generation-perennially-in sure ways, for the service of the Gospel and as a dimension of her own evangelical mandate. This is the only orthodox Christology that there is. 


\section{BIBLIOGRAPHY}

Aquinas, Summa Theologiae.

Balthasar H.U. von, Theo-Logic, II: The Truth of God, trans. by A. Walker, San Francisco 2004.

Barnes C.L., Christ's Two Wills in Scholastic Thought: The Christology of Aquinas and its Historical Context, Toronto 2015.

Basil, Epistle to Terentius (PG 32, 798 A).

Bauckham R., God Crucified: Monotheism and Christology in the New Testament, Grand Rapids 1998.

Bieler M., Analogia entis" as an expression of love according to Ferdinand Ulrich, in: The Analogy of Being: Invention of the Antichrist or the Wisdom of God?, ed. T.J. White, Grand Rapids 2011, p. 314-37.

Bulgakov S., The Lamb of God, trans. B. Jakim, Grand Rapids 2008.

Daguet F., Finis Omnium Ecclesia; Théologie du Dessein Divin chez Thomas D’Aquin, Paris 2003.

Denzinger H., Enchiridion symbolorum definitionum et declarationum de rebus fidei et morum, Forty-Third edition, ed. by P. Hünermann, R. Fastiggi, A. Nash, San Francisco 2010.

John of Damascus, On the Orthodox Faith, III, cc. 4-19, trans. S.D.F. Salmond, Nicene and Post-Nicene Fathers, Oxford 1899.

John Paul II, Fides et ratio (1998).

Maritain J., Court Traité de l'Existence et de l'Existant, Oeuvres Complètes, vol. 9, Fribourg-Paris 1990.

Newman J.H., An Essay on the Development of Christian Doctrine, London 1909.

Paul VI, Credo of the People of God.

Pius XII, Humani generis.

Przywara E., Analogia Entis; Metaphysics: Original Structure and Universal Rhythm, trans. by J. Betz, D.B. Hart, Grand Rapids 2014.

Severus Ant., Ep. I ad Sergium, CSCO 120, 60, 33-61, 9, esp. in: A. Grillmeier, Christ in Christian Tradition, vol. 2, pt. 2, London 1995.

Söhngen G., The Analogy of Faith: Likeness to God from Faith Alone?, Pro Ecclesia 21,1 (2012), p. 56-76.

Söhngen G., The Analogy of Faith: Unity in the Science of Faith, Pro Ecclesia 21,2 (2012), p. 169-194.

Tome of Leo (letter 28 to Flavian), trans. by C.L. Feltoe; ed. by P. Schaff, H. Wace, in: Nicene and Post-Nicene Fathers, vol. 12, Buffalo, NY 1895.

White T.J., Dyothelitism and the Instrumental Human Consciousness of Jesus, Pro Ecclesia 17 (2008), p. 396-422. 
White T.J., Imperfect Happiness and the Final End of Man: Thomas Aquinas and the Paradigm of Nature-Grace Orthodoxy, The Thomist 78,2 (2014), p. 247-289.

White T.J., The Incarnate Lord. A Thomistic Study in Christology, Washington, D.C. 2015.

Keywords: Chalcedonian Christology, communication of idioms, analogy, metaphysics, perennial philosophy

DLACZEGO TEOLOGIA KATOLICKA POTRZEBUJE METAFIZYKI: PERSPEKTYWA CHRYSTOLOGICZNA

\section{Streszczenie}

Chalcedoński symbol wiary zawiera prawdę o Chrystusie jako jednej osobie Syna Bożego w dwóch naturach, boskiej i ludzkiej. Doktryna współorzekania przymiotów musi być istotna dla życia i praktyki Kościoła, skoro stwierdzamy, że cechy boskie i ludzkie należą do jednego podmiotu Słowa, które stało się ciałem. Takie orzekanie nie może prowadzić do zmieszania dwóch natur lub ich odrębnych właściwości. Twierdzenie, że w Chrystusie jest boska i ludzka natura, jest jednak możliwe tylko wówczas, gdy człowiek może analogicznie myśleć o tym, czym jest boska natura, a także jednoznacznie ujmować to, czym jest natura ludzka. W przeciwnym razie nie byłoby możliwe zrozumienie boskiej natury Chrystusa i objawienie pozostawałoby zupełnie obce wobec ludzkiej myśli, nawet przy założeniu, że takie zrozumienie ma swój początek w łasce. Podobnie nie możemy myśleć o solidarności Syna z nami w ludzkiej naturze, jeśli nie przyjmujemy wspólnej nam wszystkim natury ludzkiej. Można więc stwierdzić, że Kościół może wyznawać prawdę Chalcedonu tylko wówczas, gdy istnieje wiekuista metafizyka, wewnątrz której można koherentnie myśleć o boskiej i ludzkiej naturze w ramach przyrodzonych możliwości ludzkiego rozumu. Oznacza to, że Kościół pełni funkcję „,metafizycznego apostolatu" w swoim nauczaniu, w swoich tradycjach filozoficznych, jak również w swoich twierdzeniach biblijnych i doktrynalnych.

Słowa kluczowe: chrystologia chalcedońska, współorzekanie przymiotów, analogia, metafizyka, filozofia wieczysta 